\author{
Algimantas Jankauskas, Liutauras Gudžinskas* \\ Institute of International Relations and Political Science, University of Vilnius
}

\title{
Reconceptualizing Transitology: Lessons from Post-Communism
}

\begin{abstract}
After more than a decade when a 'third wave of democratization' struck Central Eastern Europe and post-soviet space, the question is being raised regarding whether the transitional paradigm, shaped two decades ago, did not loose its theoretical and methodological capability? Does it manage to explain the political development of countries in a post communist state and especially in post soviet space?

The classical paradigm of transitology is characterized as having the following traits: (1) an aim to create a universal theory of democratization and the ability to explain processes of democratization in different social contexts; (2) the conviction that democratization is a one-way and gradual process of several phases; (3) an emphasis that the single crucial factor for democratic transition is a decision by the political elite, and not structural features; and (4) the normative belief of neoliberal nature, that the consolidation of the institute of democratic elections and other reforms of its own accord establish effectively functioning states.

This article analyses problems that appeared applying the perspective of transitology for post soviet regime change analysis and critics, shaped on these grounds. The aim is to evaluate the contemporary models of post soviet transitology that emphasize questions of state autonomy and power, examine the interaction of formal and informal institutions, use the concept of 'path dependence', and explain the different results of democratization in post soviet countries. This article will be using an example of Russia to formulate general statements that would contribute to the building of the theory of post soviet change, as well as the practical findings.
\end{abstract}

\section{Introduction}

The classical theory of transitology originally focused on the processes of the marketization and democratization of a regime. It believed that the success of the 'founding elections' and market reforms is available under any structural circumstances, if only a positive agreement by the elite on the transition has been reached. Since transitologists sought to create a theory that would be valid universally, the models of transition was created under such

\footnotetext{
${ }^{*}$ Doc. dr. Algimantas Jankauskas is an associate professor and deputy director of the Institute of International Relations and Political Science, University of Vilnius. Address: Vokiečių 10, LT-01130, Vilnius, Lithuania, tel.+370-5-2514133, e-mail: algimantas.jankauskas@tspmi.vu.lt.Liutauras Gudžinskas is a PhD candidate of the Institute of International Relations and Political Science, University of Vilnius. Address: Vokiečiu 10, LT-01130, Vilnius, Lithuania, tel.+370-5-2514130, e-mail: liutauras.gudzinskas@ tspmi.vu.1t
} 
premises and based on the experience from earlier cases of democratization in Latin America and Southern Europe, later it was tested for use in countries of the post-communist region.

However, soon it appeared that the transitions in the latter region substantially differ from earlier transitions in other parts of the world, since the majority of post-communist countries have had not only to democratise the regime and implement market reforms, but also to build a consolidated nation state. ${ }^{1}$ Despite the fact that this 'dilemma of simultaneity' was quite rapidly and successfully overcome by some post-communist countries in Central and Eastern Europe, in our view, the introduction of the term of 'triple transition' reflected a theoretical and methodological innovation important for the development of a whole transitology. More specifically, by adding a new, and seemingly only for that region typical dimension of transition, post-communist transitologists challenged the premise of the universality of explicitly actor-centred and time-and-space-ignorant original model of democratization. Moreover, it re-emphasised the stateness factor and its crucial importance for the whole process of transition.

Consequently, today one can note that transitology has 'shifted towards the state'. In fact, an analysis of 'hybrid' regimes now is hardly imaginable without the reference to state and how its functioning impacts on democratic prospects. Therefore, this general conceptual shift of transitology and its theoretical and methodological implications will be the focus of our attention in this article.

We will try to asses the linkage between the classical transitology and the most recent innovations in an attempt to show that the latter is not a radical refutation of the former, but just its revision with a larger emphasis on the real context of transition. Besides, the very concept of the state will also be separately analysed indicating the crucial implications for the whole research project if the choice to 'bring the state back in' has been made. Moreover, we will discuss the possibilities to introduce new institutionalism as a solution for overcoming the long-standing dilemma of actor-centred proceduralism and deterministic structuralism. And finally, in the last part, we will consider an example of the Russian 'democratization' which is quite instructive on how state-centred insights may be helpful in order to better understand this paradigmatic case of the 'grey' post communist regime, which arguably attracted the biggest attention of scholars.

\footnotetext{
${ }^{1}$ Offe C., "Capitalism by Democratic Design? Democratic Theory Facing the Triple Transition in East Central Europe," Social Research, 58(4), 1991, p. 865-92.
} 


\section{Transitology: Towards a New Perspective}

Five years ago Thomas Carothers published his seminal article, which declared 'the end of transition paradigm'. ${ }^{2}$ It raised no less resonance in the ranks of the transition policy experts and makers than 'The End of History' by Francis Fukuyama in 1991 who interpreted the sudden collapse of the Soviet Union as the token of the extinction of any viable alternatives to the worldwide ideologies of liberal democracy and market capitalism. ${ }^{3}$ However, the political processes following the decay of the Soviet bloc have proved over a decade that such optimism was unsound, and this was reflected by the subsequent Carothers's declaration of the end of transition paradigm.

Confronted with the fact that only a fifth (or even less) of the nearly 100 'transition' countries are really moving towards a liberal democracy, Carothers renounces the core assumptions of transition paradigm. In his words, such patterns as 'feckless pluralism' or 'dominant-power politics', is a state of normality for many developing and post-communist societies rather than the interim state between democracy and authoritarianism as transitologists usually were prone to think. Hence, according to him, the starting question in transition analysis, 'How is country's democratic transition going?' should be replaced by a more open-ended and realistic one: 'What is happening politically?'4 Such a replacement includes not only paying proper attention to the political influence of the underlying economic, social and institutional conditions, but also makes a largely neglected state-building process as the central focus of analysis.

To be correct, the issues of stateness and rule of law, have been occasionally stressed by political scientists for quite a long time, even before the Soviet Union collapsed or the very third wave of democratization occurred (Huntington: 1968, Skocpol et al.: 1985, Migdal: 1987).

However, until the second half of 1990's, the majority of transition experts (especially policy-makers and aid-practitioners) largely ignored these issues in pursuit of the implementation of specific reform packages, which were mostly based on the neoliberal (frequently anti-state) perspective. Such an uncompromising belief in the self-organizing magic of founding elections and market lasted out until the end of 1990s, when the Russian financial crisis struck in 1998, in combination with the political setback in almost the whole post-Soviet area. The disappointment with transition programme in this region coincided with similar experiences in other parts of the world. Demands for 'good governance' shifted the abstract opposition between the state and market towards a more constructive view of the role of public policy in creating an adequate institutional environment. ${ }^{5}$

\footnotetext{
${ }^{2}$ Carothers T., "The End of the Transition Paradigm”, Journal of Democracy 13:1, 2002, p. 5-21.

${ }^{3}$ Fukuyama F., “The End of History?” In The National Interest, Summer issue, 1989.

${ }^{4}$ Carothers, p. 18.

${ }^{5}$ Müller K., Pickel A., "Transition, Transformation, and the Social Sciences: Towards a New Paradigm”. TIPEC Working Paper 01/11, 2001.
} 
Hence, it is a symbolic (and a bit paradoxical) that the lessons of postcommunist transitions that were originally attempted to be analyzed by explicitly applying the experience from earlier transitions, finally crucially contributed to the significant change in the perception of these earlier transitions and of the entire phenomenon of transition.

In the next two sections we will discuss the main points of both approaches of the 'classic' democratic transition and of the 'new' state-building. It should be emphasised that the distinction of these two theoretical perspectives does not denote the clashing of two distinct academic traditions, but rather the replacement of one with another by retaining some important characteristics of former. It reminds some kind of 'genetic evolution' or 'transmutation' when the new tradition does not entirely change the old one, but preserves some its essential elements by supplementing them with a new theoretical perspective.

Table 1. Comparing approaches of transitology

\begin{tabular}{|l|l|l|}
\hline & \multicolumn{1}{|c|}{$\begin{array}{c}\text { "Democratic } \\
\text { transition" approach }\end{array}$} & "State-building" approach \\
\hline Focus of analysis & $\begin{array}{l}\text { Marketization } \\
\text { and democratization }\end{array}$ & State-building \\
\hline Methodology & $\begin{array}{l}\text { Proceduralism } \\
\text { vs. structuralism }\end{array}$ & Institutionalism \\
\hline $\begin{array}{l}\text { Conception of political } \\
\text { process }\end{array}$ & $\begin{array}{l}\text { Transition and con- } \\
\text { solidation or setback of } \\
\text { regime }\end{array}$ & $\begin{array}{l}\text { Open-ended political } \\
\text { contestation along inter-elite } \\
\text { cleavages }\end{array}$ \\
\hline Authority and society & Top-down approach & $\begin{array}{l}\text { Mutual dependence } \\
\text { and accommodation }\end{array}$ \\
\hline
\end{tabular}

\section{The Classical Transitology}

Methodologically, the birth of classical transitology can be traced back to 1970 when the seminal article of Dunkwart Rustow was published. ${ }^{6}$ It challenged the then prevailing structuralist approach and emphasized the primary significance of the political elites' will to initiate the country's transition to a democracy. In other words, it stated that there are actually no social and economic preconditions, the absence of which could preclude the political and economic reforms towards democracy. This actor-oriented approach became

\footnotetext{
${ }^{6}$ See Rustow R. , "Transitions to democracy: toward a dynamic model”, Comparative Politics, Vol. 2, 1970, p. 337-363.
} 
dominant in mid 1980's. ${ }^{7}$ It stressed that the collective choices of elites, if taken under the right circumstances and at the right time, can cancel out at least temporarily, the negative effects of such structural factors as a low level of development and education, unfavourable colonial legacies or religious traditions, ethno-linguistic fractionalization etc.. ${ }^{8}$ Therefore, it provided some kind of optimism that there is a real possibility to establish a democratic political system in almost any country in the world, if the correct decisions are made at the critical moment by relevant actors.

One of the main assumptions of classical transitology theory was that the democratization occurs in a set sequence of stages. First, there occurs the political liberalization and the opening of the authoritarian regime; secondly, there follows the breakthrough or the transition to democracy - the most crucial stage when founding elections are held and new democratic government comes to power. Finally, there comes a consolidation, a slow and long-term process when the elections are regularized, the state institutions are reformed and civil society is strengthened, which means the overall habituation of the society to the democratic order. ${ }^{9}$

The distinction between the phases of democratic transition and consolidation here will be emphasised. Transition is defined as a distinctive moment in the political life and trajectory of a country - a period of unknown duration and extraordinary uncertainty - that is generally initiated from the dynamics within the authoritarian regime. It is precisely this extraordinary state of uncertainty that is the chief feature of a transition from authoritarian rule. ${ }^{10}$ It leads us to two conclusions: firstly, because of its inherent uncertainty, transition can lead either to democracy or to another type of regime, e.g. some kind of soft authoritarianism. Secondly, in such times of 'abnormal politics', structural preconditions matter less then short-term strategic calculations of elites, and if these calculations are positively interlinked with the isolation of hardliners of regime and the reached broad consensus on the change of regime, a new democracy can emerge. ${ }^{11}$

Two distinct albeit interdependent processes - democratization and marketization - appeared as the focus of attention for classical transitologists. The market transition programme was mostly based on the so-called 'Washington consensus'. ${ }^{12}$ It proposed a 'shock therapy' strategy that meant the simultaneous and rapid implementation of several comprehensive measures such as the Liberalization of prices, mass privatization, tight fiscal and monetary

\footnotetext{
${ }^{7}$ O’Donnell G., Schmitter P.C., Transitions from Authoritarian Rule: Prospects for Democracy, Johns Hopkins University Press, 1986.

${ }^{8}$ Karl T.K., "From Democracy to Democratization and Back: Before Transitions from Authoritarian Rule”. CDDRL Working paper Number 45, 2005, P. 11.

${ }^{9}$ Carothers, p. 7.

${ }^{10}$ Karl, p. 6.

${ }^{11}$ Ibidem, p. 9-10.

12 The term was coined by O. Williamson in 1990 to name the neoliberal economic reform strategy that occurred after Latin American debt crisis in 1980s.
} 
policy, the introduction of convertible currency, the removal of state monopolies, and etc.. The attractiveness of the 'shock therapy' was in part due to the promise that in principle all societies were capable of establishing the basic institutions of a modern market economy regardless of their history, the state of the economy, or their previous social and political settings. On the other hand, the proponents of market transition (especially in post-communist countries) saw it not only as an economic, but also as a political strategy for dismantling of old state structures. By stating that under the market 'many economic problems solve themselves' they emphasised the beneficial effects of self-organizing markets in comparison of intervention of state into the economy. It was also a justification for the anti-statist character of the politics of marketization and privatization as a means of eliminating those interest groups that still occupied the institutions of old regime. ${ }^{13}$

Meanwhile, regarding the theory of the democratization of regime, the central importance of the 'founding elections' has been emphasised largely. It has been assumed that in attempt to transition to a democracy, free and fair elections are not just a foundation stone but a key generator over time of further democratic reforms. ${ }^{14}$ Hence, the conceptual model of an electoral democracy has become the dominant in judgement regarding whether the country had reached the minimal standards of democracy. According to this model, democracy has been defined as the process by which 'individuals acquire the power to decide by means of a competitive struggle for the people's vote. ${ }^{15}$ Another widely used model includes additional dimension, i.e. a set of major civic and political rights and freedoms that serves as a basic indicator of democracy. ${ }^{16}$ Therefore, the bulk of transition literature has focused on measuring and comparing the level of democracy in transition countries.

However, some qualifications have to be made as to what has already been said. Firstly, it is not clear how much transitions are 'uncertain' or 'abnormal', and do all transitions share the same degree of unpredictability? Indeed, one can hardly find a name for such structural factors that in any case would determine (or preclude) the transition to democracy, but it is also hardly convincible that the influence of structural factors is so negligible that it may be ignored, that being analyzing the outcomes of any transition. Therefore, the elites' decisions at the moment of transition (no matter how uncertain or abnormal it is) should be viewed as "occurring in settings of 'structured contingency', in which choices are circumscribed by pre-transitional, economic, cultural and other structural factors." 17

Secondly, transitologists tended to assume that the mode of transition is a key aspect, by which the fragments and parts of the new regime are constructed and which help to shape the post-transitional regime in a distinctive way. By

\footnotetext{
${ }^{13}$ Müller, Pickel

${ }^{14}$ Carothers, T. (2002): Op. cit., p. 8.

${ }^{15}$ Schumpeter J., Capitalism, socialism, and democracy. New York: Harper, 1947, p. 269.

${ }^{16}$ Dahl R. A., Democracy and its critics. New Haven and London: Yale University Press, 1989.

${ }^{17}$ Karl, p. 12.
} 
stressing the importance of the mode of transition, there have been attempts to indicate which modes of transitions are the most positive to the prospect of consolidation of democracy. However, contrary to initial expectations, by using quantitative methods it has been revealed that democracy can be consolidated irrespective of their differing modes of transition, and any mode of transition (even 'pacted') per se does not determine the success of transition. The point is that these modes are highly contextualized and their different impacts, if they exist in some systemic way, are likely to be indirect and identifiable with other causal factors, both structural and procedural. ${ }^{18}$

Thirdly, the three-stage transition model is overly teleological and is not able to fully grasp the essence of so-called hybrid regimes. The work of Guillermo O'Donnel and Philippe Schmitter, in 1986, originally underlay, the transition model which used much broader notion of regime transition (not of democratic transition). However we still do not have the parallel model that could explain the consolidation of non-democratic regimes. Meanwhile, the identification of regimes (that are not of consolidated democracy) with specific adjectives (such as 'delegative democracy', 'hybrid democracy', 'populist democracy', 'illiberal democracy', etc.) 'only states the research problem, rather than solves it, ${ }^{\prime 19}$ because it is not clear whether such a hybrid regime is more autocratic or democratic and what are the prospects of its further development.

Since these regimes do not follow the underlain logic of democratic transition, the focus of analysis is to be shifted to such political processes that go beyond democratization and marketization. The recent turn for emphasizing the central role of the state and its transformation's impact on democratic transition or another trajectory of development of political regime might be one of the most promising ways to respond to the challenges that are confronted by today transitology.

\section{The State-Building Approach}

State-building is a profoundly complex issue that includes not only the solution of territorial questions, the creation of state apparatus or the evolution of national identity, but also the strengthening of state infrastructural powers and the establishment of the rule of law in its territory. One can argue that its central importance goes even beyond another two transitions, i.e. democratization and marketization, since 'if the state cannot project authority within its borders, then it is unlikely to be able to provide the basic framework required for the establishment of any coherent development project' ${ }^{20}$

\footnotetext{
${ }^{18}$ Ibidem, p. 25-30.

${ }^{19}$ Gel'man V., "Post-Soviet Transitions and Democratization: Towards Theory Building”, Democratization, Vol. 10, No. 2 Summer 2003, p. 91.

${ }^{20}$ Stoner-Weiss K., Resisting The State: Reform and Retrenchment in Post-Soviet Russia, Cambridge:

Cambridge University Press, 2006, p. 7.
} 
By this interpretation, therefore, the issue of stateness becomes of central importance not only concerning post-communist countries, but also for all developing countries, including those that usually were treated as 'double transition' cases. As Guillermo O'Donnell has emphasised, 'states are interwoven in complex and different ways with their respective societies. This embeddedness means that the characteristics of each state and of each society heavily influence the characteristics of what democracy will be likely (if at all) to consolidate - or merely endure or eventually break down. ${ }^{21}$

As many third-wave democratizing states remain unable to fulfil the developmental promises made at the start of their transitions, one can argue that the issue to which we should turn now is not just the kind of government in any particular state (democratic or authoritarian), but the degree of government and the state's actual capacity to govern. ${ }^{22}$

In this context the definition of state includes not only the Weberian reference to the state's monopoly over legitimate means of violence, but also encompasses its institutional capacity to maintain the order by mere compliance from society and without resorting to the actual use of force. Michael Mann distinguishes infrastructural and despotic powers, where despotic power is the 'power of the state elite over civil society, infrastructural power is the ability of the state to penetrate and centrally coordinate the actions of civil society. ${ }^{23}$ It is the infrastructural (and not despotic) power that is at the core of modern state capacity.

Such a distinction also helps to grasp better 'the paradox of the power of strong state' that has been revealed by Joel Migdal. According to Migdal, the power of a strong state is usually invisible, contrary to the power of a weak state that is naked and obviously repressive, since it is not able to internalize successfully its norms into the society and thus to extract compliance from the society without unqualified coercion. ${ }^{24}$ In addition, the question of 'state autonomy' (or 'state capture', on the other side) emerges, since a crucial contributor to state's capacity, authority and stability is its infrastructural base - a bureaucracy that has to have some degree of autonomy from societal interests and that can also provide a reliable mechanism of control and coherence.

However, one cannot forget the fact that the state, as a concept, is not a material object, but an analytical abstraction. ${ }^{25}$ There are several grand theories (pluralism, elitism, Marxism, etc.) that treat the state itself and its impact on politics differently, although it is possible to discern some formal organizational

\footnotetext{
${ }^{21}$ O’Donnel G., "On the State, Democratization and Some Conceptual Problems: A Latin American View with Glances at Some Post communist Countries", World Development, 21(8), 1993, p.1355.

${ }^{22}$ Stoner-Weiss K., p. 12.

${ }^{23}$ Mann M., "The Autonomous Power of the State," in John Hall (ed.) States in History. Blackwell, 1986, p. 112.

${ }^{24}$ Migdal J., "Strong Societies, Weak Societies: Power and Accommodation" in Myron Weiner and Samuel Huntington (eds.) Understanding Political Development, Boston: Little Brown, 1987.

${ }^{25}$ Patrick Dunleavy P., O'Leary B., Theories of the State: The Politics of Liberal Democracy, Basingstoke: Palgrave Macmillan. 1987.
} 
and functional characteristics of modern state that could fit into the perception of the state provided by any of these theories. Such a common denominator of definition of the state may include the reference to the aforementioned the Weberian definition of state and additional (functional) dimension that emphasises the state's duty to keep the order in its territory.

Nevertheless, even if there is such a common denominator that provides the general characteristics of this conceptual abstraction (i.e. the modern state) it is still not clear what analytical use we may expect to get by applying this concept. In other words, what is the reason that could justify the choice of researcher 'to bring the state back in' analysis of any political phenomenon (including democratic transition)?

Although a much more theoretical deliberation is required in order to answer such a question, some basic intuitions may be provided. According to Colin Hay and Michael Lister, the state provides a context within which political actors are seen to be embedded and with respect to which they must be situated analytically. Such a context (or institutional landscape) is 'strategically selective', i.e. more conducive to certain strategies and preferences of certain actors than others. The actors are hence constrained by such selective terrain, since they must orient themselves if they are to realize their intentions. Moreover, the state contextualizes the agency not only institutionally, but historically as well. For whilst governments may come and go, the state - as an institutional ensemble - persists, as it evolves over time. That evolution is shaped by both the intended and unintended consequences of governing strategies and policies. To understand the capacity for governmental autonomy is, then, to asses the extent of the institutional, structural and strategic legacy inherited from the past. ${ }^{26}$

Therefore, the introduction of the concept of state into political analysis may help us justify why institutions and history matter for the political process. On the other hand, 'state-centred' approaches, in turn, can be accused of their determinism, if constraints on the actions, strategies and preferences of actors are overemphasised. It reminds us of a long-standing clash between proceduralism and structuralism which is clearly seen in the case of methodology of transitology. As we have already mentioned before, the classical actor-oriented transitology emerged by challenging the then-prevailing structuralist approach and stating that there are no social, economic and other structural preconditions that could preclude the establishment of democratic regime in any country of the world.

Nevertheless, we argue that this old dilemma of structuralism versus proceduralism may be solved exactly by introduction of the term of stateness into the analysis of democratic transitions. The focus on the stateness issues in the transition analysis may be methodologically and theoretically grounded by the recently developed (and still developing) perspective of 'new institu-

\footnotetext{
${ }^{26}$ Hay C., Lister M., "Introduction: Theories of the State", in Colin Hay, Michael Lister and David Marsh (eds.), The State: Theories and Issues, Bassingstoke: Palgrave Macmillan, 2006, p. 10-12.
} 
tionalism', which encompasses quite a wide range of hypotheses on reciprocal causal relations between actors and institutions.

New institutionalism as a broad theoretical perspective has developed since the 1980s in reaction to the behavioural perspectives and seeks to elucidate the role that institutions play in the determination of social and political outcomes. The core theoretical insight of new institutionalism is that the patterning of social life is not produced solely by the aggregation of individual and organizational behaviour, but also by the institutions that structure action. ${ }^{27}$ It is necessary to emphasize that new institutionalism recognizes the importance of procedural factors (and by this premise it differs from 'older' institutional theories), but at the same time tries to develop some particular theoretical models that could help us better understand how actors and institutions interact with each other.

The intimate relationship between actors (humans) and institutions is reflected in the very definition of institution. According to the widely accepted definition, institutions are humanly devised rules of game that shape the interaction of humans themselves. ${ }^{28}$ In this context it also necessary to emphasise the distinction between institutions as rules and popular perception of institutions as organizations that are collective actors and thus not to be included into the definition of institution used by new institutionalism.

Such from the first glance a seemingly tautological relationship in fact provides various possibilities to formulate the possible causal links between actors and (constraining) institutional factors in a more nuanced way. In fact, the very field of new institutionalism is highly fragmented, since there are several institutionalist approaches that differ among themselves quite significantly. Nevertheless, in our case it enables one at the same time to compare the various hypotheses about the causal relations among institutions and actors, ranging from the economic institutionalism as the most procedural institutionalist approach to the sociological institutionalism as the most structural one.

Table 2. The four approaches of new institutionalism

\begin{tabular}{|l|l|l|}
\hline \multicolumn{1}{|c|}{$\begin{array}{c}\text { Approach of new } \\
\text { institutionalism } \\
\text { (model, logic of action) }\end{array}$} & \multicolumn{1}{|c|}{$\begin{array}{c}\text { The hypothesised link } \\
\text { between actors and } \\
\text { institutions }\end{array}$} & \multicolumn{1}{|c|}{ Authors } \\
\hline $\begin{array}{l}\text { Economic institution- } \\
\text { alism (the functional } \\
\text { model, the logic of } \\
\text { instrumental action) }\end{array}$ & $\begin{array}{l}\text { Actors create institutions that } \\
\text { provide solutions to problems } \\
\text { of collective action. When } \\
\text { institutions become less func- } \\
\text { tional, they are substituted } \\
\text { with more effective ones. }\end{array}$ & $\begin{array}{l}\text { Williamson (1975), } \\
\text { Goodin (1996), Eggert- } \\
\text { son (1990), Putterman }\end{array}$ \\
\hline
\end{tabular}

\footnotetext{
${ }^{27}$ Clemens E. S., Cook J. M, "Politics and Institutionalism: Explaining Durability and Change", Annual Review of Sociology, Vol. 25, 1999, p. 442.

${ }^{28}$ North D.C, Institutions, Institutional Change, and Economic Performance, Cambridge: Cambridge University Press, 1990.
} 


\begin{tabular}{|l|l|l|}
\hline $\begin{array}{l}\text { Rational choice institu- } \\
\text { tionalism (the model of } \\
\text { 'veto players', the logic } \\
\text { of instrumental action) }\end{array}$ & $\begin{array}{l}\text { Institutions affect the } \\
\text { strategies of actors in the } \\
\text { interaction with other actors. } \\
\text { Established institutions may } \\
\text { be suboptimal, since they } \\
\text { reflect the problems of public } \\
\text { choice and of compatibility of } \\
\text { the interests of individually } \\
\text { rational 'veto players'. }\end{array}$ & $\begin{array}{l}\text { Tsebelis (2002), Sharpf } \\
\text { (1997), Shepsle (1986), } \\
\text { Bates et al. (1998) }\end{array}$ \\
\hline $\begin{array}{l}\text { Historical institutional- } \\
\text { ism (the model of 'path } \\
\text { dependence'; combines } \\
\text { both logics of instru- } \\
\text { mental action and of } \\
\text { appropriateness) }\end{array}$ & $\begin{array}{l}\text { Actors tend to adapt to insti- } \\
\text { tutions rather than to change } \\
\text { them, even if institutions } \\
\text { bring unintended and not } \\
\text { very much desired effects. } \\
\text { The earlier decisions shape } \\
\text { the later ones. The more time } \\
\text { passes, the more institutions } \\
\text { resilient become and the } \\
\text { more cost are necessary to } \\
\text { change them. }\end{array}$ & $\begin{array}{l}\text { Pierson (2004), North } \\
\text { (1990), Thelen (2004), }\end{array}$ \\
\hline $\begin{array}{l}\text { Sociological institu- } \\
\text { tionalism (the cultural } \\
\text { model, logic of appro- } \\
\text { priateness) }\end{array}$ & $\begin{array}{l}\text { Institutions shape not only } \\
\text { the strategies, but also the } \\
\text { preferences of actors. The } \\
\text { importance of informal } \\
\text { rules that dictate how actors } \\
\text { behave in the most 'socially } \\
\text { appropriate' way. }\end{array}$ & $\begin{array}{l}\text { March\&Olsen (1989), } \\
\text { Powell\&DiMaggio } \\
\text { (1991) }\end{array}$ \\
\hline
\end{tabular}

So far we have argued that new institutionalism is a theoretical perspective that is directly linked with the state-centred analysis and might perhaps best methodologically ground the latter, since the state is broadly perceived as the institutional ensemble.

However, one cannot forget that the market and the elections (which are at the central focus of classical transitology) are the institutions as well. Therefore, the perspective of new institutionalism may be applied for the grounding of the basic premises of classical transitology and, what is the most important, to provide the uniting theoretical link between procedural classical transitology and institutional state-building theories.

From the table on the four approaches of new institutionalism given above, we may see that classical transitology, presupposing self-organizing and functional qualities of democratic political and economic institutions, has much in common with the economic institutionalism, i.e. the most procedural version of new institutionalism.

This version treats institutions functionally, i.e. as capable of reducing transaction costs and solving problems of collective action. If institutions are not able to do that, they are changed by actors with the more effective rules 
that give a competitive advantage against other acting units (for e.g. states). Therefore, in the long-term perspective one may expect that that there would be competition-driven worldwide convergence of (the most effective) rules of political and economic systems.

The similar argument is used by classical transitologists who tend to assert that in principle it depends on the agreement of elite to adopt free elections and market rules in their country. Since these democratic political and economic institutions are considered to be as the most effective in generating the progress and responding the essential needs of society, one day they should become universal.

That this is not the case (especially in case of adoption of political institutions of democracy), we experience it from today's reality, which teaches us that the scenario of democratic regress may also be very probable. That is why we need to check another hypotheses that recognize larger role for the state as a particular institutional ensemble. From the table given above we see that there can be at least other three underlying hypotheses for explanation and prediction of outcomes of transition in a particular case.

Firstly, the non-democratic regime (if such occurred after transition) may be interpreted as the reflection of particular fixed equilibrium among the most important actors of state that have rational interests incompatible with the full implementation of transition project (rational choice institutionalism). Secondly, in transition there may be the so-called effect of 'path dependency', which means the inertia of state institutions and their earlier development trends even under the circumstances of globally changed environment (historical institutionalism). And lastly but not least, transition and its outcomes can be influenced by certain cultural (informal) traditions that are in contention with the ideology of liberal democracy and of the rule of law (sociological institutionalism).

As it was indicated before, the verification of such a hypothesis and also the evaluation of a state's infrastructural power (that is necessary for successful fulfilling transition project) requires contextualised research. This is not inconsiderable qualification, since it limits (though does not preclude) the application of state-centred theories in a quantitative manner.

However, even if such research can be conducted only by case study or small-N comparison, there is a possible methodological alternative to the application of statistical methods, i.e. so-called 'systematic process analysis'. As Peter Hall stresses, taking seriously the principle that 'correlation is not causation', such methodology assesses the adequacy of a theory not only by inspecting key causal variables and outcomes but by comparing theory's predictions about causal processes with multiple observations about such processes in the cases at hand. ${ }^{29}$ Taking into mind that the transition, first of all, is a process, and the

\footnotetext{
${ }^{29}$ Hall P. A., "Aligning Ontology and Methodology in Comparative Politics", in James Mahoney, Dietrich Rueschemeyer (eds.), Comparative Historical Analysis in the Social Sciences, Cambridge: Cambridge University Press, 2003, p. 399.
} 
introduction of state means the historical and institutional contextualization, such a systematic process to the analysis, which considers the importance of distant events, sequencing and complex interaction, may be an adequate methodological instrument for the further development of today transitology.

In the last section we will take an illustrative example of the Russian case and review some the most recent works on political development of this country that use the state-centred insights in order to explain why democracy in this paradigmatic case of the post communist country that attracted probably the biggest attention of researchers has failed.

\section{Russian Case: The Application of the State-Building Approach}

Until the mid-1990s the bulk of the transition literature dealing with the post-communist region largely ignored stateness. It tacitly assumed that post-communist transitions would follow the pattern of earlier transitions in Southern Europe and Latin America. In these two regions the focus was upon only two areas - democratization and marketization - because these transitions took place within long-established states. ${ }^{30}$ In 1996, Juan Linz and Alfred Stepan asserted that 'stateness problems must increasingly be a central concern of political activists and theorists alike. ${ }^{\prime 31}$

Therefore, the notion of the 'triple transition' became increasingly applied in the post-communist studies (and later for almost all transition cases), since most countries of this region simultaneously had to cope with the state-building task along with democratization and marketization, ${ }^{32}$ which may be counted as the additional challenge for transition process.

What aggravated the post-communist transition process even more, is the poor institutional legacy of the old regime. According to the well-known argument of Linz and Stepan, the type of pre-democratic regime is one of the crucial factors that determine the success of consolidation of democracy. And considering this aspect, the post-totalitarian past is reckoned to be as less positive circumstance for transition than the legacy of authoritarian regime which was a case in the countries of Latin America and Southern Europe. ${ }^{33}$ As Jon Elster, Claus Offe and Ulrich K. Preuss asserted, virtually everything has been affected by the conditions and habitats of old post-communist regime. More

\footnotetext{
${ }^{30}$ Kuzio T., "Transition in Post-Communist States: Triple or Quadruple?", Politics Vol. 21(3), 2001, p. 168.

${ }^{31}$ Linz J., Stepan A., Problems of Democratic Transition and Consolidation. Southern Europe, South America and Post-Communist Europe, Baltimore: John Hopkins University Press, 1996.

${ }^{32}$ Kuzio adds another one "transition", i.e. nationhood issue, as crucially important for the former Yugoslavia, USSR and Slovakia. However, we choose to treat it as an integral albeit important element of state-building process.

${ }^{33}$ Linz, Stepan
} 
specifically, such inherited constrains include the state of material resources and their organization, the 'inner environment' of mental residues, including the cognitive and normative culture, and the established elites and their informal power resources. At the same time the post-communist countries after the collapse of the pre-democratic regime were confronted with the situation when the political agency was weak and scattered. ${ }^{34}$

Nevertheless, some scholars have recently challenged this 'dilemma of simultaneity' pointing out that despite ostensibly poor institutional legacy, many countries in the post-communist region have achieved the same or an even higher level of consolidation as the young democracies in southern Europe and Latin America, and furthermore they did so in a much shorter time. ${ }^{35}$ One of the most valid explanations of this phenomenon could be that the post-communist states have inherited a much more developed structure of 'infrastructural power' in comparison with the majority of countries of Latin America and other regions, which helped some of the former in better implementation of transition project. Therefore, according to such interpretation, the post-communist institutional legacies might be even a positive factor.

On the other hand, it reflects the existence of variety in post-communist region how state-building processes evolve during transition. Anna Grzymala-Busse and Pauline Jones Luong argue that these processes of post-communist state-building are still unfolding and have not reached a stable end-point. They define state formation as a competitive process of establishing authority over a given territory. This process consists of individual or institutional actors of elite who face different modes of competition (self-contained or representative) and employ different mechanisms to win this competition (formal or informal structures and practices). Thus the various combinations of these modes and mechanisms produce different degrees of elite constraint and popular compliance, which, in turn, comprise distinct state-building trajectories. Those post-communist countries that experienced the representative competition among elites and employed formal structures and practices to resolve this competition, have quite successfully consolidated democracies. Such countries include Hungary, Poland, the former Czechoslovakia, Slovenia, and the former Baltic republics. These countries have a common history of communist rule imposed on previously independent states, which fostered an antagonistic relationship between rulers and ruled and, thus, served to reinforce this state-society division. Where the boundary between state and society was blurred under communism and, hence, former ruling elites did not face mobilized opposition (in Russia and in many of the other former Soviet republics), we find self-contained (i.e. non-accountable and less responsive) competition. ${ }^{36}$

\footnotetext{
${ }^{34}$ Jon Elster J., Offe C., Preuss U.K., Institutional Design in Post-communist Societies: Rebuilding the Ship at Sea. Cambridge University Press, 1998, p. 19.

${ }^{35}$ Croissant A., Merkel W., "Introduction", in Aurel Croissant and Wolfgang Merkel (eds.), Consolidated or defective democracies? Problems of Regime Change, Special Issue of Democratization vol. 11, no. 5, December 2004, p. 1-10.

${ }^{36}$ Grzymala-Busse A., Luong P., J., “The Ignored Transition: Post-Communist State Development”. Paper No. 02-02, March 2002.
} 
There are also other recent works that demonstrate the impact of Russian state-building processes for prospects of democratization of this country.

Allen C. Lynch in his book "How Russia is not ruled" asserts that the evolution of the neo-patrimonial political system in Russia after the collapse of Soviet Union is not the new trend but rather the reproduction of the long-term state development trajectory. Russia, confronted with harsh geographic conditions and a hostile international environmental, since the Medieval Age when it occurred as the Muscovite state, has relied on extensive and despotic state power in order to compete with other international powers both economically and militarily. Although such regime based on the narrow basis and alienated from the society had been sometimes successful, it could not finally cope with new social and economic impulses from modernising society and has therefore collapsed twice in the $20^{\text {th }}$ age - after the First World War and the Cold War.

Russia's path of development, in this light, has been one of (a) concentration of virtually unaccountable power in the hands of the executive, a concentration that at times is able to mobilize resources to perform extraordinary tasks but is not conducive to legal rationality in respect of persons and property; and (b) the absence of a clear line between property and political power. The fundamental test for Russia in the 1990s, was to change this essential unaccountability of executive power and within it to take the chance of establishing the rule of law that is the prerequisite of both capitalist and democratic development. That Russia entered the twenty first century with an executive authority that was largely unaccountable to the formal institutions of state and a continued merger of political power and economic wealth (albeit in new forms) suggests just how powerful Russia's historical path of development was. ${ }^{37}$

Meanwhile, Vladimir Gel'man seeks to re-define the concept of regime in order to explain the outcomes of post-communist transition combined with the formation of state. To his opinion, post-Soviet pacts (in difference from 'pacts' in earlier transition countries) were merely cartels of incumbents against contenders, cartels that restrict competition, bar access, and distribute the benefits of political power among the insiders. The formation of the imposed consensus' of Russia's elites under Vladimir Putin is a good example. These 'pacts' have not enforced democratization, but blocked it. Hence, the very basis of political contestation depended upon intra-elite cleavages, because of the weakness of societal cleavages and growing dependence of mass clienteles upon elite's patronage. In Russia, a zero sum game solution of intra-elite conflicts during the 1991-1993 and later elections undermined any incentives for the ruling group to accept bounds on their own powers by strengthening formal institutions. What is open to argument is whether the 'bad equilibrium' of dominance of informal institutions is now 'destined' to be reproduced over time and become self-perpetuating. ${ }^{38}$

Similarly, Kathryn Stoner-Weiss, in line with the definition of state-buil-

\footnotetext{
${ }^{37}$ Lynch, A., C., How Russia Is Not Ruled. Cambridge University Press, 2005, p.170.

${ }^{38}$ Gel'man, p. 93-97.
} 
ding as competitive process, in her book Resisting the State argues that the postcommunist state-building project in Russia was subverted by well-entrenched economic elites who had little incentive or interest in building the state's regulatory capacities at the expense of their own private extractive opportunities. On the contrary, they had every incentive to continue to resist the state oversight of their activities and even to actively tear the state down and continue to grab its assets. ${ }^{39}$ More precisely, Stoner-Weiss argues that it was the landslide and rapid privatization that was dominated by insider interests within the bulk of Russian enterprises consolidated strong, but particularistic societal interests. The new 'entrepreneurchiki', formerly members of Soviet nomenclature, were determined to prevent the new Russian state from regulating their rent seeking activities. These groups benefited from the stalled reforms (when Jegor Gaidar as prime minister was replaced by Victor Chernomyrdin) and have an interest in preventing further change. They preferred to co-opt regional governments (or colluded directly with them) to prevent the central state from effectively regulating their activities. ${ }^{40}$ Therefore, Stoner-Weiss finds that in contrast to many expectations, the post-communist project has been to tear the state down through predation in order to enrich a narrow slice of Russian society that consisted most of the members of former Soviet state structures. ${ }^{41}$

To sum it up, the rule of Putin could be evaluated as an effort to regain the power and capacity of state that was torn down following the collapse of Soviet Union and the mass privatization. The capacity of state is tried to be increased by the restraining the political contestation and taming the most important social and economic actors. However, the politics of dominant-power is prevailing in Russia, and while there is a significant lack of rule of law, the prospects for representative competition among elite forces by formal means tend to be very modest.

\section{Conclusion}

To rephrase a famous quotation of Mark Twain, the report of transitology's death was an exaggeration. What transitology experienced, nevertheless, is a certain redesigning of its main concept. The teleological universal model of transition has been substituted with a more realistic and contextualised one.

The main new element that has been introduced into the general concept of transition is a notion on necessity to build a functioning state. In other words, the task of 'triple transition' that was firstly 'assigned' only for the countries in the post communist region is to be applied for all countries that are 'in transition', 'State weakness', 'state capture' or even 'state failure' are increasingly recognised as the essential reason why 'feckless pluralism' or 'illiberal democracy' prevail in many countries of the world.

\footnotetext{
${ }^{39}$ Stoner-Weiss, p. 8.

${ }^{40}$ Ibidem , p.15.

${ }^{41}$ Ibidem , p. 21.
} 
The introduction of the state has its further methodological implications and trade-offs for transitology. On the one hand, it requires contextualising the research, since the very concept of state may be analytically useful for us if it gives us a sufficient view of historical and institutional landscape in which real political processes evolve. Hence, the introduction of state into research to some extent is also a certain methodological choice, as it prefers single or small-N case more than quantitative analysis. On the other hand, it does not preclude the possibility for a 'middle-range' theory building through a theoretical perspective of new institutionalism that may generate various theoretical models encompassing both procedural and structural factors.

All in all, although its initial optimism was not fully justified, transitology with its revised form has still a lot of potential to develop further, since its essential normative aim - to help with democratising the world - remains crucially important.

\section{Bibliography}

1. Bates, Robert, et al., Analytical Narratives. Cambridge: Cambridge University Press, 1998.

2. Carothers, Thomas, "The End of the Transition Paradigm" Journal of Democracy 13:1, 2002.

3. Clemens, Elisabeth S. and James M. Cook, "Politics and Institutionalism: Explaining Durability and Change", Annual Review of Sociology, Vol. 25, 1999.

4. Croissant, Aurel S. and Wolfgang Merkel, Consolidated or defective democracies? Problems of Regime Change, Special Issue of Democratization vol. 11, no. 5, December 2004.

5. Dahl, A. Robert, Democracy and its critics. New Heaven and London, 1989.

6. Dunleavy, Patrick and Brendan O'Leary, Theories of State: The Politics of Liberal Democracy, Palgrave, 1987.

7. Eggertson, Thrainn, Economic Behaviour and Institutions, Cambridge: Cambridge University Press, 1990.

8. Elster, Jon, Claus Offe, Ulrich K. Preuss, Institutional Design in Post-communist Societies: Rebuilding the Ship at Sea. Cambridge: Cambridge University Press, 1998.

9. Fukuyama, Francis, “The End of History?”, The National Interest, Summer issue, 1989.

10. Gel'man, Vladimir, “Post-Soviet Transitions and Democratization: Towards Theory Building”, Democratization, Vol. 10, No. 2, Summer 2003.

11. Goodin, Robert E. (ed.), The Theory of Institutional Design, Cambridge: Cambridge University Press, 1996.

12. Grzymala-Busse and Anna Pauline Jones Luong. "The Ignored Transition: Post-Communist State Development”, Paper No. 02-02, March 2002. 
13. Hay, Colin, Michael Lister and David Marsh (eds.), The State: Theories and Issues, Bassingstoke: Palgrave Macmillan, 2006.

14. Huntington, Samuel, Political Order in Changing Societies. New Haven: Yale University Press, 1968.

15. Karl, Terry Lynn. "From Democracy to Democratization and Back: Before Transitions from Authoritarian Rule", CDDRL Working paper Number 45, 2005.

16. Kuzio, Taras, “Transition in Post-Communist States: Triple or Quadruple?", Politics Vol. 21(3), 2001.

17. Linz, Juan and Alfred Stepan, Problems of Democratic Transition and Consolidation. Southern Europe, South America and Post-Communist Europe, Baltimore: John Hopkins University Press, 1996.

18. Lynch, Allen C., How Russia Is Not Ruled Cambridge: Cambridge University Press, 2005.

19. Mahoney, James and Dietrich Rueschemeyer (ed.), Comparative Historical Analysis in the Social Sciences, Cambridge: Cambridge University Press, 2003.

20. Mann, Michael, "The Autonomous Power of the State" in John Hall (ed.) States in History. Blackwell, 1986.

21. March, James and Johan Olson. Rediscovering Institutions: The Organizational Basis of Politics. New York: Free Press, 1989.

22. Migdal, Joel, "Strong Societies, Weak Societies: Power and Accommodation" in Myron Weiner and Samuel Huntington (ed.) Understanding Political Development, Boston: Little Brown, 1987.

23. Müller, Klaus, and Andreas Pickel, "Transition, Transformation, and the Social Sciences: Towards a New Paradigm”, TIPEC Working Paper 01/11, 2001.

24. North, Douglass C., Institutions, Institutional Change, and Economic Performance, Cambridge: Cambridge University Press, 1990.

25. O'Donnel, Guillermo. "On the State, Democratization and Some Conceptual Problems: A Latin American View with Glances at Some Post communist Countries", World Development, 21(8), 1993.

26. O’Donnell, Guillermo and Philipp Schmitter, Transitions from Authoritarian Rule: Prospects for Democracy, Johns Hopkins University Press, 1986.

27. Offe, Claus, "Capitalism by Democratic Design? Democratic Theory Facing the Triple Transition in East Central Europe" Social Research, 58(4), 865-92, 1991.

28. Pierson, Paul, Politics in Time: History, Institutions, and Social Analysis, Princeton: Princeton University Press, 2004.

29. Powell, Walter W., ir Paul DiMaggio (ed.), The New Institutionalism in Organisational Analysis, Chicago: University of Chicago Press, 1991.

30. Putterman, Louis, (ed.), The Economic Nature of the Firm, Cambridge: Cambridge University Press, 1986.

31. Rustow, Dankwart, "Transitions to democracy: toward a dynamic model”, Comparative Politics, Vol. 2, 1970, p. 337-363. 
32. Schumpeter, Joseph, Capitalism, Socialism and Democracy. New York: Harper, 1947.

33. Sharpf, Fritz W., Games Real Actors Play: Actor-Centred Institutionalism in Policy Research. Boulder, Colo.: Westview Press, 1997.

34. Shepsle, Kenneth A., "Institutional Equilibrium and Equilibrium Institutions" in Herbert F. Weisberg, ed., Political Science: The Science of Politics, p. 51-81. New York: Agathon Press, 1986.

35. Skocpol Theda, "Bringing the State Back In: Strategies of Analysis in Current Research" in Peter B. Evans, Dietrich Ruescheymeyer and Theda Skocpol (eds.), Bringing the State Back In, Cambridge: Cambridge University Press, 1985.

36. Stoner-Weiss, Kathryn. Retrenchment and Reform in Post-Soviet Russia, Cambridge: Cambridge University Press, 2006.

37. Thelen, Kathleen, How Institutions Evolve: The Political Economy of Skills in Germany, Britain, Japan and the United States. New York: Cambridge University Press, 2004.

38. Tsebelis, George, Veto Players: How Political Institutions Work, Princeton: Princeton University Press, 2002.

39. Williamson, Oliver E., Markets and Hierarchies: Analysis and Antitrust Implications. Chicago: Free Press, 1975. 